\title{
Phytochemical Analysis and Wound Healing Potential of Ethanol Extract of Sea Mustard and Sea Mustard Sporophyll
}

\author{
Jin Kim ${ }^{1, *}$, Chang-Moon Lee $\mathrm{L}^{2,3, \dagger, *}$ and Su-Gwan Kim ${ }^{1, \dagger, *}$ \\ ${ }^{I}$ Department of Oral and Maxillofacial Surgery, College of Dentistry, Chosun University \& \\ Institute of Dental Science, Chosun University, Gwangju 61452, Korea \\ ${ }^{2}$ Department of Biomedical Engineering, Chonnam National University, Yeosu 59626, Korea \\ ${ }^{3}$ Research Center of Healthcare Biomedical Engineering, Chonnam National University, Yeosu 59626, Korea
}

In this study, phytochemicals extracted from sea mustard (SM) and sea mustard sporophyll (SMS) in ethanol solution have been analyzed and wound healing potential of the phytochemicals was investigated. In the phytochemical screening studies, the extract of SM and SMS includes several phytochemical compounds such as phytol, ascorbic acid, sitgmasta, fucosterol and ergosta. Cytotoxicity studies of the extract of SM and SMS with mouse macrophage RAW 264.7 cells showed on toxicity up to a high concentration of $1.0 \mathrm{mg} / \mathrm{mL}$. Furthermore, the SM and SMS extract significantly reduces the production of nitric oxide (NO) induced lipopolysaccharide on RAW 264.7 cells with a dose-dependent manner. In addition, the extract of SM and SMS has the effect of enhancing the cell migration and invasion of fibroblast. These results demonstrate that the extract of SM and SMS could help to heal wound by reducing NO production and increasing cell migration

Key Words: Sea mustard, Sea mustard sporophyll, Phytochemical, Tissue-regeneration

\begin{abstract}
서 론
최근 천연물소재로부터 효능이 우수한 물질을 찾아내 고 생리활성 기능을 이용한 바이오소재의 연구가 활발히 진행되고 있다. 특히, 해양생물의 생리기능이나 유용 물 질을 산업에 이용하려는 노력이 급증하면서 해양생물은 생명공학의 주요 자원으로 급부상하고 있다(Guaratini et al., 2012). 해양 식물의 경우, 우리나라는 전통적으로 미역,
\end{abstract}

다시마 및 김 등의 해조류를 식품으로 이용해 왔다. 해조 류의 생리활성 성분을 활용하여 약품, 화장품, 식품 등의 물질을 개발하고자 많은 연구가 진행되고 있다(Gupta and Abu-Ghanna, 2011). 또한, 천연소재 기반 연구가 다양화 되면서 창상치료에 효능을 가지는 천연물에 연구개발이 활발해지고 있다. 특히, 상처치유 반응은 염증-증식-재형 성의 3단계 과정을 거친다(Pasparakis et al., 2014). 어느 한 과정이라도 지연되거나 시행되지 않으면 만성적인 상처 로 전환돼 치료와 흉터 제거에 비용과 시간이 소요된다.

Received: July 1, 2019 / Revised: November 30, 2019 / Accepted: December 5, 2019

${ }^{\dagger}$ To whom correspondence should be addressed.

* Professor.

† Corresponding author: Su-Gwan Kim. Department of Oral and Maxillofacial Surgery, College of Dentistry, Chosun University \& Institute of Dental Science, Chosun University, Gwangju 61452, Korea.

Tel: +82-62-230-6883, Fax: +82-62-608-5407, e-mail: cream4251@ chosun.ac.kr

Corresponding author: Chang-Moon Lee. Department of Biomedical Engineering, Chonnam National University \& Research Center of Healthcare Biomedical Engineering, Chonnam National University, Yeosu 59626, Korea.

Tel: +82-61-659-7631, Fax: +82-61-659-7369, e-mail: cmlee@jnu.ac.kr

(C) The Korean Society for Biomedical Laboratory Sciences. All rights reserved.

(c) This is an Open Access article distributed under the terms of the Creative Commons Attribution Non-Commercial License (http://creativecommons.org/licenses/by-nc/3.0/) which permits unrestricted non-commercial use, distribution, and reproduction in any medium, provided the original work is properly cited. 
이런 이유로 상처가 발생한 초기에 피부와 표피 조직 재 생을 촉진시키는 조성 물질 연구가 중요하다(Rousselle et al., 2018).

식물에서 생리활성을 가지는 추출물의 성분은 항균, 혈 관형성, 염증반응, 세포확산, 혈관생성촉진 및 조직 재생 에 중요한 역할에 관여하고 있다(Surh et al., 2001).

미역(Undaria pinnatifida sporophyll)은 갈조 해조류로서 무기질, 비타민 및 섬유질 성분, 점질성 다당류, 아이오 딘을 함유하고 있다. 약리적 효능으로 항암효과가 있는 fucoidan과 세포막의 구성 성분으로 다량 존재하는 alginic acid 등에 산성 다당류가 있다. Fucoidan, alginic acid는 갈조 류의 다당류로 묽은 산이나 염기 혹은 열수로 추출되며 이들 수용성 다당류들은 식이 섬유소로 정장작용, 콜레스 테롤의 수치를 낮추는 등의 효과뿐만 아니라 만성적인 상 처와 관련하여 항 혈액응고, 항균, 항바이러스 활성 등도 보고되었다(Torres et al., 2014).

이러한 약리적 효능을 활용하여 치유과정이 매우 복잡 하고 정교한 분화과정을 가지는 상처치유 소재로 활용 가 능성을 관찰하였다.

미역의 일부분이며 alginic acid 함량이 높은 것으로 알 려진 미역귀는 일부 식용으로는 사용하고 있으나 식품개 발품에서 소외되고 연구가 미비한 점을 착안하여 본 연 구를 시도하게 되었다. 기존의 연구에서는 미역과 미역귀 각각의 소재를 추출하여 후코이단(Fucoidan) 성분의 항균, 항염, 염증 관련 cytokine 측정을 진행한 연구와 미백 및 보습과 관련한 효능 연구가 대부분이다(Song et al., 2015; Lee et al., 2018)

본 연구에서는 갈조류에 속하는 미역과 미역귀 해조류 를 에탄올 $70 \%$ 로 추출하여 GC-MS로 성분을 비교하고, 생리활성 성분의 함량을 확인하였으며, 상처치유에 관여 하는 소재로 활용 가능성을 평가하였다.

\section{재료 및 방법}

\section{시약}

본 실험에 사용한 미역(SM, sea mustard)과 미역귀(SMS, sea mustard sporophyll) 분말은 어업회사법인 (주)씨스타 에서 제공받았다. 추출물의 항산화능 및 항염증 측정 실 험에 사용된 1-1-diphenyl-2-picryl-hydrazyl (DPPH), tannic acid, gallic acid, Folin-ciocalteu phenol reagent 및 Griess reagent 등은 Sigma Chemical Co. (St. Louis, MO, USA)에서 구입하였다. 세포독성 측정에 사용된 대식세포의 일종인
RAW 264.7과 섬유아세포 NIH 3T3는 Korean Cell Line Bank (KCLB)에서 구입하여 실험에 이용하였다. Dulbecco's Modified Eagle Medium (DMEM), Fetal Bovine Serum (FBS), penicillin-streptomycin 등의 세포배양 관련 시약은 Invitro$\operatorname{gen}\left(\mathrm{Gibco}^{\mathrm{TM}}\right.$, Carlsbad, CA, USA) 사에서 구입하였다.

\section{추출 방법}

분쇄한 SM과 SMS 분말의 $20 \mathrm{~g}$ 에 3 배의 $70 \%$ 에탄올에 침지시켜 probe sonication을 3 시간 처리하고 whatman filter paper로 여과한 다음 추출액을 얻고, 감압농축기에서 에 탄올을 증발시켰다.

\section{추출물의 생리활성 정량}

항산화 효과를 측정하기 위한 전자공여능을 측정하였다. 각 시료 용액 $1 \mathrm{mg} / \mathrm{mL}$ 농도의 용액 $2 \mathrm{~mL}$ 에 $0.2 \mathrm{mM}$ 의 $\mathrm{DPPH} 1 \mathrm{~mL}$ 넣고 교반 후 30 분간 암실에서 방치한 후 $517 \mathrm{~nm}$ 에서 흡광도를 측정하였다. 전자공여능은 시료 용 액의 첨가군과 무첨가군의 흡광도 감소율로 나타내었다. 총 폴리페놀 함량은 $1 \mathrm{mg} / \mathrm{mL}$ 로 고정 농도로 제조하여 희 석한 시료 용액 $3 \mathrm{~mL}$ 에 Folin-Ciocalteu phenol reagent 시 약 $1 \mathrm{~mL}$ 를 가하고, 포화용액 $\mathrm{Na}_{2} \mathrm{CO}_{3} 1 \mathrm{~mL}$ 를 가하여 혼합 한 후 1 시간 실온에서 방치하고, $700 \mathrm{~nm}$ 에서 흡광도를 측 정한 후, 표준 물질인 tannic acid와 gallic acid로 미리 작성 한 표준곡선의 흡광도 값을 비교하여 폴리페놀 함량을 산 출하였다. 추출물의 미생물 생육저지능 유무를 확인하기 위하여 Staphylococcus aureus (SA), Staphylococcus epidermidis $(\mathrm{SE})$ 를 사용하여 생육저지환을 확인하였다.

\section{추출물의 GCMS 평가}

추출물의 성분 분석을 위하여 gas chromatography/mass spectroscopy (GC-2010, Shimadzu Co., Kyoto, Japan) 기기를 통해 관찰하였다. 추출물을 에탄올에 충분히 교반한 후, 원심분리기를 이용하여 부유물을 제거하고 마이크로 필터 $(0.45 \mu \mathrm{m})$ 로 여과하여 준비하였다. 성분 분석은 다음과 같 은 조건으로 진행하였다. 컬럼은 BD-5 $(60 \mathrm{~mm} \times 0.25 \mathrm{~mm}$ $\times 0.25 \mathrm{~mm})$, carrier gas로는 $\mathrm{He}(1 \mathrm{~mL} / \mathrm{min})$, injection 온도는 $250^{\circ} \mathrm{C}$, oven 온도는 $5 \sim 300^{\circ} \mathrm{C} / 3^{\circ} \mathrm{C}$ 승온, injection volume은 $1 \mu \mathrm{L}$, injection mode는 split ratio 10:1 조건에서 성분 분석 을 하였으며, MSD (mass selective detector)에서 mass range 28 550, acqusition mode는 scan mode 조건으로 성분들을 정량하였다. 
Table 1. Total phenolic and flavonoid contents, antioxidant and antibacterial activities of extract

\begin{tabular}{lccccc}
\hline \hline Sample & $\begin{array}{c}\text { Total phenolic comp } \\
\text { ound }(\mathrm{mg} / \mathrm{g})\end{array}$ & $\begin{array}{c}\text { Flavonoid content } \\
(\mathrm{mg} / \mathrm{g})\end{array}$ & $\begin{array}{c}\text { Free radical } \\
\text { scavenging }(\%)\end{array}$ & \multicolumn{2}{c}{ Diameter of inhibition zone (mm) } \\
\cline { 5 - 6 } & $12.37 \pm 0.8$ & $1.2 \pm 0.3$ & $53.96 \pm 3.4$ & $8.4 \pm 0.12$ & $9.2 \pm 0.2$ \\
SM & $23.56 \pm 0.21$ & $13.2 \pm 0.4$ & $74.17 \pm 2.8$ & $7.2 \pm 0.12$ & $7.1 \pm 0.1$ \\
\hline
\end{tabular}

*SA: Staphylococcus aureus, "SE: Staphylococcus epidermidis Paper disc $6 \mathrm{~mm}(0.6 \mathrm{~cm})$

\section{세포독성 측정}

동결건조된 분말 형태의 SM과 SMS 추출물을 DMEM 배양배지에 희석하여 농도별로 처리하였다. 시료의 독성 평가는 MTT assay 방법을 활용하여 NIH 3T3 세포를 분주 하고 세포 생존률을 평가하였다. 96 well plate에 각 well 당 세포 $5 \times 10^{4} \mathrm{cells} / \mathrm{well}$ 를 분주하고 24시간 후 다양한 농도로 제조한 추출물을 함유한 배양액으로 갈아준 후 24 시간 동안 $37^{\circ} \mathrm{C}, 5 \% \mathrm{CO}_{2}$ 조건에서 배양하였다. Well 당 $20 \mu \mathrm{L}$ 의 MTT 용액을 첨가하여 4시간 동안 반응시킨 후, 배양액을 버리고 DMSO $100 \mu \mathrm{L}$ 씩 넣어 formazan을 용해 한 후, ELISA 측정기(ELX 808, Bio tek Instruments, Vermont, $\mathrm{USA}$ )을 이용하여 $570 \mathrm{~nm}$ 에서 흡광도를 측정하였다.

\section{항염증 평가}

$\mathrm{SM}$ 과 SMS 추출물의 항염증성을 평가하기 위해 RAW 264.7 세포에 lipopolysaccharide (LPS)를 처리하여 발생되 는 nitric oxide (NO)의 양을 측정하였다. 96 well plate에 RAW 264.7 세포가 $5 \times 10^{4}$ cells/well이 되도록 분주한 후 12 시간 배양하였다. Well에 다양한 농도의 SM과 SMS 추 출물을 처리하고 LPS $(1 \mu \mathrm{g} / \mathrm{mL})$ 를 첨가하였다. 24시간 후 세포 배양액의 $50 \mu \mathrm{L}$ 와 같은 양의 Griess Reagent를 넣어 주고 10 분간 반응시킨 후 $540 \mathrm{~nm}$ 파장에서 흡광도를 측 정하고 $\mathrm{NaNO}_{2}$ 의 표준곡선을 이용하여 정량하였다.

\section{세포이동성 평가}

추출물이 세포의 이동성에 주는 영향을 평가하기 위하 여 접촉저해 상태의 단층세포에 형성된 상처영역으로 이 동하는 세포를 관찰하였다(Wiegand et al., 2019). SM과 SMS 추출물에 의한 세포이동(Cell migration) 촉진 여부를 평가하기 위해 48 well plate에 $5 \times 10^{4} \mathrm{cell} / \mathrm{mL}$ 의 농도로 $\mathrm{NIH} 3 \mathrm{~T} 3$ 섬유아세포(fibroblast)를 분주하여 세포배양기 $\left(37^{\circ} \mathrm{C}, 5 \% \mathrm{CO}_{2}\right)$ 에서 24 시간 배양한 후, 세포단층에 200 pipet tip으로 scratch를 가해 빈 공간을 만들고, 혈청을 포
함하지 않은 배지를 처치한 그룹과 SM과 SMS 추출물을 처치한 후, 24 시간 배양하였다. 실험군의 세포이동 정도를 현미경을 이용해 빈 공간의 간격을 측정하여 대조군과 비 교하였다.

\section{통계처리}

모든 실험 결과는 평균값(mean)과 표준편차(standard deviation, SD)로 표시하였다. 대조군과 실험군 사이의 통 계학적 유의성 검정은 Student's $t$-test로 비교하였으며 $P$ 가 0.05 이하인 것만 유의한 것으로 하였다.

\section{결 과}

\section{추출물의 생리활성 평가}

해조류 추출물의 총 페놀과 플라보노이드 함량을 분석 하였으며 추출물의 항균 실험을 진행한 결과 값은 Table 1 과 같다. 추출물의 생리활성을 나타내는 화합물 중 폴리 페놀류의 화합물의 대부분은 hydroxyl group을 갖고 있으 며 이와 관련된 항산화 연구는 보고된 바가 있다(Lee et al., 1997). 해조류 추출물의 총 폴리페놀에 의한 항산화 활성을 확인하였다. SM과 SMS의 총 페놀 함량은 12.37 , $23.56 \mathrm{mg} / \mathrm{g}$ 으로 나타났으며 플라보노이드 함량은 $1.2,13.2$ $\mathrm{mg} / \mathrm{g}$ 으로 확인되었다. Kim 등은 다시마 및 미역 추출물에 서 폴리페놀 함량은 $3.91,3.55 \mathrm{~m} / \mathrm{g}$ 의 함량이 보고되었다 (Kim et al., 2012). Ahn 등의 연구에서는 해조류 추출물의 성분 분석 결과 총 폴리페놀과 플라보노이드의 총당 및 환원당 함량은 해조류 종류에 따라 차이가 나며 갈조류는 폴리페놀과 플라보노이드 함량이 상대로 높으며, 홍조류 와 녹조류는 상대적으로 총당 함량이 높은 결과가 보고되 었다(Ahn et al., 2010).

DPPH radical은 안정한 free radical로 다른 원자 및 분자 로부터 전자 혹은 양성자를 받아들여 안정한 분자로 변하 는 성질이 있다. 추출물의 $1 \mathrm{mg} / \mathrm{mL}$ 농도의 $\mathrm{DPPH}$ 의 소거 활성 활성능은 $\mathrm{SM}$ 은 $54 \%, \mathrm{SMS}$ 에서는 $74 \%$ 의 항산화 활 


\section{성을 나타내었다.}

추출물의 항균 실험 결과 SM과 SMS 추출물의 $1 \%$ 농 도에서 항균 저해능의 경우 $\mathrm{SM}$ 추출물이 $\mathrm{SE}$ 균주에서 가장 높은 생육저해환이 관찰되었다. Lee 등의 연구에서 해조류에서 추출한 후코이단 추출물의 $1 \%$ 에서 $1.52 \mathrm{~cm}$ 의 저해환이 관찰되었다(Lee et al., 2018).

\section{추출물의 성분 분석}

해양 식물로 선정한 SM과 SMS 추출물의 성분 분석을 GC-MS를 이용하여 측정하였다(Fig. 1). 해조류 추출물은 농축하여 얻은 일정의 분말을 유기용매에 용해시켜 성분 을 분석하였다. 유효 성분들은 총 14 종으로 확인되었다 (Table 2). 특히, 락톤 구조를 가지는 ascorbic acid 성분은 $\mathrm{SMS}$ 에서 SM보다 두배가 넘는 것을 확인하였다. 하지만 2 개의 이중 결합을 가지는 불포화지방산인 octadecadienoic acid 즉, linoleic acid의 경우 SM과 SMS에서 비슷함 함량 을 가진 것을 확인하였다. 식물 오일(Vegetable oil)에서만 추출되는 Stigmasta-3,5-dien-7-one 화합물의 경우 SM에서 3 배 더 높은 것을 확인하였다. 또한, 항산화, 항염증, 항암 에 효능이 입증된 fucosterol, ergosta-5,7,22-trien-3beta-ol 성 분의 경우 $\mathrm{SM}$ 에서 4 배가 높이 함유된 것을 관찰하였다. 전체적으로 지방산과 항산화 효능을 가진 화합물 성분을 확인하였다(Stierle et al., 2006).

\section{추출물의 세포독성 평가}

추출물을 100 10,000 ppm 농도로 NIH 3T3에 추출물을 처리한 결과 $10,000 \mathrm{ppm}(1 \%)$ 의 고농도에서도 세포생장 에 영향을 주지 않은 것을 확인하였다(Fig. 2). 추출 성분 이 체내 안정성이 높은 것으로 확인되었으며, 추출물의 생리활성은 의약품, 화장품, 식품 등의 다양한 응용이 가
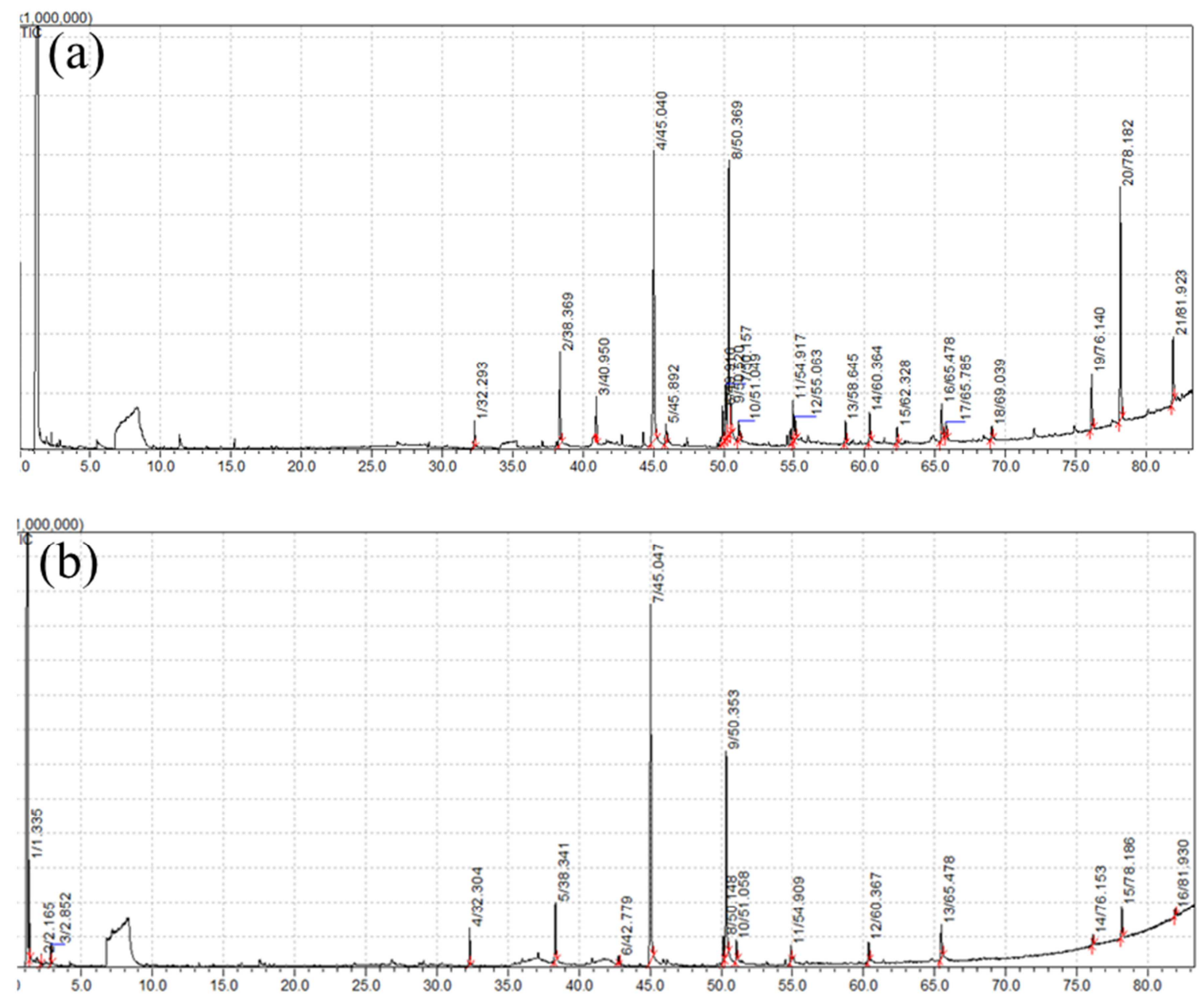

Fig. 1. GCMS of SM and SMS extract. 
Table 2. Chemical compound of the SM and SMS extract by GC-MS

\begin{tabular}{|c|c|c|c|c|c|}
\hline \multirow{2}{*}{ Peak } & \multirow{2}{*}{ Real. time } & \multirow{2}{*}{ Library } & \multicolumn{2}{|c|}{ Area $(\%)$} & \multirow{2}{*}{ Effect } \\
\hline & & & SM & SMS & \\
\hline 1 & 32.2 & Propionic acid & 1.35 & 3.12 & Saturated fatty acid \\
\hline 2 & 38.36 & Tetradecanoic acid & 5.88 & 5.68 & Saturated fatty acid \\
\hline 3 & 40.95 & Phytol & 2.04 & - & Anti-oxidant \\
\hline 4 & 45.04 & Ascorbic acid & 23.48 & 45.96 & Anti-oxidant \\
\hline 5 & $45,50,58,62,65$ & Cyclononasiloxane & 6.83 & - & Anti-bacteria \\
\hline 6 & 49.91 & Methyl eicosa-7,10,13-trienoate & 2.42 & - & Polyunsaturated fatty acid \\
\hline 7 & $50,51,65$ & Octadecadienoic acid & 27.52 & 31.04 & Polyunsaturated fatty acid \\
\hline 8 & 54.91 & Arachidonic acid & 2.82 & 1.55 & Polyunsaturated fatty acid \\
\hline 9 & 55.06 & Eicosapentaenoic acid & 1.62 & - & Polyunsaturated fatty acid \\
\hline 10 & 60.36 & Haxadecanoic acid & 2.08 & 2.03 & Saturated fatty acid \\
\hline 11 & 69.03 & Tetracosamethyl-cyclododecasiloxane & 0.97 & - & Anti- inflammatory \\
\hline 12 & 76.14 & Stigmasterol & 3.78 & 1.08 & $\begin{array}{l}\text { Anti-oxidant, } \\
\text { Anti- inflammatory }\end{array}$ \\
\hline 13 & 78.18 & Fucosterol & 14.60 & 3.44 & $\begin{array}{l}\text { Anti-oxidant, } \\
\text { Anti- inflammatory }\end{array}$ \\
\hline 14 & 81.92 & Ergosterol & 4.61 & 0.66 & $\begin{array}{l}\text { Anti-oxidant, } \\
\text { Anti- inflammatory }\end{array}$ \\
\hline
\end{tabular}

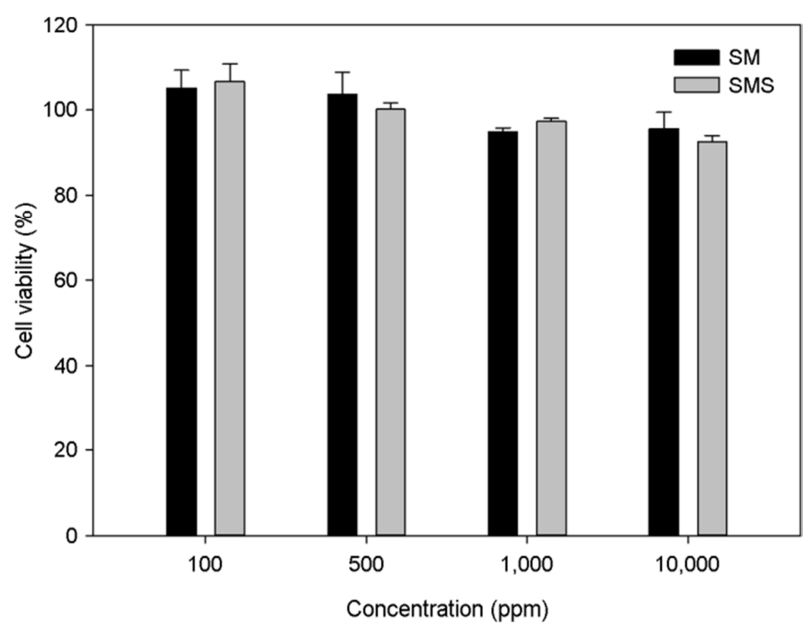

Fig. 2. Evaluation of cell viability by MTT assay on NIH 3 T3 cell line treated with SM and SMS extract.

능할 것으로 사료된다.

\section{항염증 평가}

염증반응의 표지 인자로 사용되는 Nitric oxide (NO)는 대식세포와 같은 면역세포에서 생성되어 각종 병리 및 생 리적 과정에 있어 중요한 역할을 하는 것으로 알려져 있
다(Moncada et al., 1991), 추출물이 NO의 생성에 미치는 영향을 조사함으로서 염증 저해능을 평가하였다. LPS로 처리된 RAW 264.7 세포로부터 해조류 추출물이 농도에 따라 $\mathrm{NO}$ 의 생성을 농도 의존적으로 저해되는 것을 관찰 하였다. 정상세포에서는 각각 $4.2 \pm 0.8,3.26 \pm 0.74 \mu \mathrm{g} / \mathrm{mL}$ 의 $\mathrm{NO}$ 가 생성되는 반면, LPS만 처리한 군에서는 43.6土 $2.57,47.5 \pm 3.28 \mu \mathrm{g} / \mathrm{mL}$ 의 $\mathrm{NO}$ 가 생성되었다. 실험군 $\mathrm{SM}$ 과 SMS 추출액을 처리한 $10,50,100,1,000 \mu \mathrm{g} / \mathrm{mL}$ 의 농도에 서 세포로부터 생성되는 $\mathrm{NO}$ 의 양은 $\mathrm{SM}$ 에서는 $34.7 \pm 5.2$, $25.03 \pm 2.9,12.96 \pm 1.62,11.36 \pm 0.6 \mu \mathrm{g} / \mathrm{mL}$ 였다. 또한, $\mathrm{SMS}$ 의 경우 $32.9 \pm 1.48,24.06 \pm 1.3,17.46 \pm 1.67,13.3 \pm 0.7 \mu \mathrm{g} / \mathrm{mL}$ 로 $\mathrm{SM}$ 과 $\mathrm{SMS}$ 추출액이 고농도에서 $\mathrm{NO}$ 의 생성량이 현저히 감소되는 것을 확인할 수 있었다(Fig. 3). Endotoxin인 LPS 를 처리하여 염증지표인 $\mathrm{NO}$ 의 생성을 유도하고 각 추출 물을 처리하여 NO 생성 저해효과를 확인함으로써 해조류 의 추출물이 항염증 효과를 보이는 것을 확인할 수 있었 다(Kim and Lee, 2018).

\section{세포이동률 평가}

섬유아세포를 이용하여 세포이동성 시험(Cell migration assay)을 통해 해조류 추출물 $0.1 \%$ 처리한 군에서 처리하 지 않은 군보다 빠른 이동과 증식이 확인되어 양단간의 


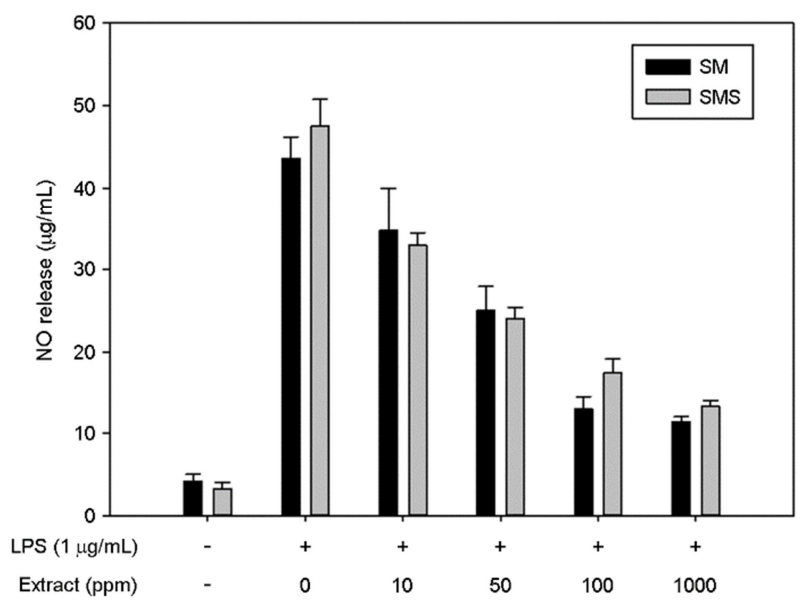

Fig. 3. Inhibition of LPS-induced NO production by SM and SMS extract.

간격이 좁아졌다. 해조류 추출물을 24시간이 후부터 간격 이 서서히 좁아지는 것을 확인되었고, 대조군에 비해 간 격이 많이 좁아진 양상이 확인되었다(Fig. 4). 이와 같은 결과로 해조류 추출물 성분 내에 Vitamin C 성분이 항산 화 효능을 갖고 있어, mitochondria integrity 유지 및 세포손 상 억제에 도움을 줄 수 있다고 추측할 수 있다(Kim et al., 2012). 생리활성을 가지는 식물 추출물의 항산화 작용은 화상으로 인한 피부상처의 조직 재생을 위해 mitochondria integrity를 유지하는데 도움을 주고 세포손상을 억제하는 것으로 알려져 있다(Zang et al., 2007).

\section{고 찰}

천연물 자원을 활용한 새로운 의약품소재 개발 연구가 활발해짐에 따라 식물 자원을 이용한 생리활성 효능 평가 및 기능성 평가를 통해 생활에 다양한 활용을 시도하고 있다. 특히, 해양 식물소재 유래 천연물 성분 등은 오랜 기간 동안 식용 또는 약용으로 사용되어 그 안전성 및 약 효성이 입증되어 보고되고 있다(Noda et al., 1989).

다양한 천연 추출물의 상처치유력은 추출물의 자유라 디컬소거 작용과 생리활성 분자(bio active molecules)가 단 일작용 혹은 서로 상승작용(synergy effect)에 의해 빠른 상 처치유력에 도움을 준다(Okoli et al., 2007).

천연 식물 중 해양 식물에 포함되는 해조류 중 미역과 미역귀를 에탄올을 이용하여 추출하였다. 추출물의 생리 활성 성분을 확인하고 항산화능, 항염증능, 세포이동률 확 인하였다.

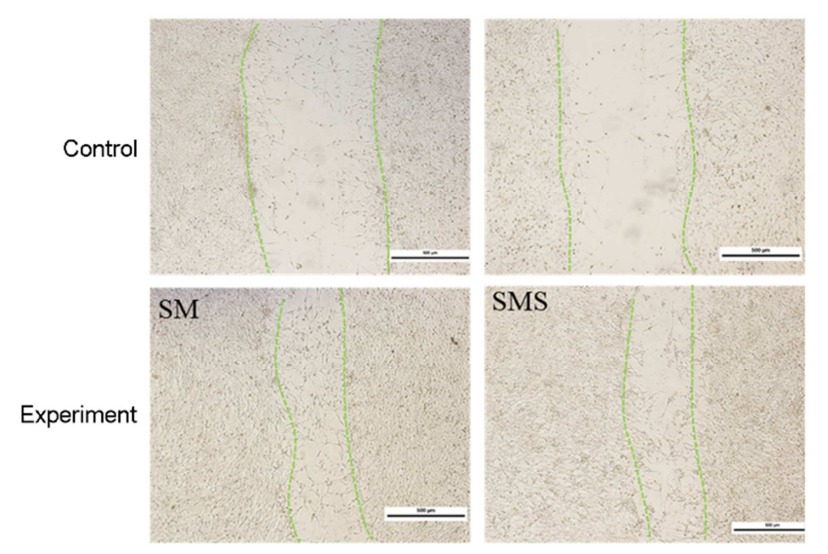

Fig. 4. Cell migration assay by SM and SMS extract $(\times 4)$. Cell were treated with SM and SMS after wounding.

미역과 미역귀에서 생리활성 화합물로 phytol, ascorbic acid, sitgmasta, fucosterol, ergosta 성분과 지방산 성분이 확 인되었다. 특히, 미역귀 추출물에서 ascorbic acid가 $45.96 \%$ 가 확인되었다. Ascorbic acid (vitamin C) 성분은 대표적으로 항산화 물질로 알려져 있으며, 배양된 피부아세포(human skin fibroblast)에서 type I형 procollagen 합성을 자극하기 때문에 collagen 생성을 조절하는 작용을 한다(Dumas et al., 1996; Chung, 1997).

인체 내 산화적 스트레스와 밀접한 관계가 있는 자유 라디칼은 환경오염, 음주, 흡연, 화학약품 등과 같은 외부 환경에 의해 생성되며, 생체 내 자유라디칼과 반응하여 생성되는 활성 산소종(reactive oxygen species, ROS) 및 산 화질소(nitric oxide, $\mathrm{NO}$ )는 단백질 불활성화와 조직의 손 상 및 유전자 변이들을 유발하여 노화, 퇴행성질환, 대사 중후군, 암과 같은 질환의 주요 원인으로 보고되고 있다 (Alfadda and Sallam, 2012; Khurana et al., 2013). 자유라디칼의 제거에 영향을 주는 항산화제(antioxidant) 평가는 $\mathrm{DPPH}$ 라디칼을 이용하여 안정한 형태의 화합물로 전환되면 서 정량적으로 탈색되어 진한 보라색에서 옅은 노란색으 로 변하는 원리를 이용한 방법으로 $\mathrm{SM}$ 추출물보다 SMS $(1 \mathrm{mg} / \mathrm{mL})$ 에서 $74 \%$ 로 $\mathrm{SM}$ 추출물보다 약 1.4 배 높은 항 산화능이 관찰되었다(Blois, 1958).

다시마에서 분비되는 물질 중 황산기가 함유된 후코이 단이 추출되며, 이 추출물의 항균 활성이 보고되었다(Lee et al., 2018). 또한, 갈조류 해조에서 추출되는 식물성 스 테롤(Phytosterol)인 stigmasterol, fucosterol, ergosterol 등의 sterol 유도체가 SMS 추출물보다 SM 추출물에서 더 많이 함유된 것을 확인하였다. SM 추출물에서 더 높은 항균력 
이 관찰되었다. 이는 phytosterol성분이 항균효과에 작용하 는 연구와 같은 결과를 확인하였다(Burčová et al., 2018). 고농도인 $1 \%$ 에서 추출물의 세포독성 평가 결과 독성 이 없었으며, $\mathrm{NO}$ 를 관찰한 결과 $\mathrm{SM}$ 과 $\mathrm{SMS}$ 추출물에서 농도 의존적으로 항염증에 관여하는 것을 확인하였다. 특 히, phytosterol의 sterol 유도체의 함량이 더 많은 SM 추출 물에서 더 높은 NO 저해능을 관찰하였다. Phytosterol 성 분은 식용 갈조류에 함유된 항염증 성분으로 널리 알려져 있으며 본 연구에서도 phytosterol의 함량이 더 높은 $\mathrm{SM}$ 추출물에서 NO 저해능이 높은 경향이 관찰되었다(Jung et al., 2013).

세포이동률을 측정한 결과 $\mathrm{SM}$ 과 $\mathrm{SMS}$ 에서 세포이동과 증식을 확인할 수 있었다. 상처치유능은 복잡한 생물학적 과정이므로 생체 내에서 쉽게 연구가 불가능하다. 그러나 동물세포를 이용한 in vitro assay 방법을 통해 조직 재생 및 상처치유에 대한 물질과 물질에 대한 영향을 쉽게 관 찰할 수 있다. 세포생존 능력, 증식 및 형태 뿐만 아니라 상처치료의 체외 평가방법으로 포괄적으로 접근하는 방법 중 하나이다(Wiegand et al., 2019). 세포이동능은 진피에서 지속적으로 증식하여 표피로 이동하여 각질세포로 분화 하기 위한 일반적인 생리활성이다. 상처로 인한 피부 재 생을 위해서는 매우 중요한 세포활성 기능 중에 하나이다 (Kim et al., 2011; Kim, 2016).

따라서, 본 연구 결과는 에탄올에 침지시켜 추출한 $\mathrm{SM}$ 과 $\mathrm{SMS}$ 의 생리활성 결과는 식품뿐 아니라 의약품, 화장 품 등에 활용 가능할 것으로 판단되며 세포 재생 관련 소재로 활용가치가 있을것으로 기대된다.

\section{ACKNOWLEDGEMENT}

This research was a part of the project titled 'Development of Bioabsorbable Membrane Comprising Marine Organism Derived Extract for Guided Bone Regeneration', funded by the Ministry of Oceans and Fisheries, Korea.

\section{CONFLICT OF INTEREST}

No potential conflict of interest relevant to this article was reported.

\section{REFERENCES}

Ahn SM, Hong YK, Kwon GS, Sohn HY. Evaluation on in-vitro anticoagulation activity of 35 different seaweed extracts.
Journal of Life Science. 2010. 20: 1640-1647.

Alfadda AA, Sallam RM. Reactive oxygen species in health and disease. Journal of Biomedicine and Biotechnology. 2012. 936486.

Blois MS. Antioxidant determinations by the use of a stable free radical. Nature. 1958. 181: 1199-1200.

Burčová Z, Kreps F, Greifová M, Jablonský M, Ház A, Schmidt Š, Surina I. Antibacterial and antifungal activity of phytosterols and methyl dehydroabietate of Norway spruce bark extracts. Journal of Biotechnology. 2018. 20: 18-24.

Chung JH, Youn SH, Kwon OS, Cho KH, Youn JI, Eun HC. Regulations of collagen synthesis by ascorbic acid, transforming growth factor-beta and interferon-gamma in human dermal fibroblasts cultured in three-dimensional collagen gel are photoaging and aging independent. Journal of Dermatological Science. 1997. 15: 188-200.

Dumas M, Chaudagne C, Bonte F, Meybeck A. Age-related response of human dermal fibroblasts to 1-ascorbic acid. study of type I and III collagen synthesis. Comptes Rendus de l'Académie des Sciences - Series III - Sciences de la Vie. 1996. 319: 1127 -1132 .

Guaratini T, Lopes NP, Marinho-Soriano E, Colepicolo P, Pinto E. Antioxidant activity and chemical composition of the non polar fraction of Gracilaria domingensis (Kützing) Sonder ex Dickie and Gracilaria birdiae. Brazilian Journal of Pharmacy. 2012. 22: 724-729.

Gupta S, Abu-Ghanna N. Bioactive potential and possible health effects of edible brown seaweeds. Trends in Food Science \& Technology. 2011. 6: 315-326.

Jung HA, Jin SE, Ahn BR, Lee CM, Choi JS. Anti-inflammatory activity of edible brown alga Eisenia bicyclis and its constituents fucosterol and phlorotannins in LPS-stimulated RAW 264.7 macrophages. Food and Chemical Toxicology. 2013. 59: 199-206.

Khurana S, Piche M, Hollingsworth A, Venkataraman K, Tai TC. Oxidative stress and cardiovascular health: Therapeutic potential of polyphenols. Can. The Korean Journal of Physiology \& Pharmacology. 2013. 91: 198-212.

Kim J, Lee CM. Anti-inflammatory effects and influence on fibroblast growth of astaxanthin-cyclodextrin nanoparticles. Journal of Chitin and Chitosan. 2018. 23: 170-175.

Kim JW, Kwon YR, Youn KS. Quality characteristics and antioxidant properties in spray-dried and freeze-dried powder prepared with powdered seaweed extracts. Korean Society of 
Food Science and Technology. 2012. 44: 716-721.

Kim JS, Bak EJ, Lee BC, Kim YS, Park JB, Choi IG. Neuregulin induces HaCaT keratinocyte migration via Rac1-mediated NADPH-oxidase activation. Journal of Cellular Physiology. 2011. 226: 3014-3021.

Kim JS. Effect of rudbeckia laciniata extract on physiological activity of HaCaT Cells, The Korean Journal of Food and Nutrition. 2016. 29: 335-340.

Kim HS, Lee JH, Yeon CJ, Lee JS. The therapeutic effect of porcine placenta extract for improvement sequelae of burn. Journal of Korean Burn Society. 2012. 15: 96-101.

Lee AR, Roh SS, Kim HK. Anti-microbial activity and antiinflammatory effects of fucoidan extracts. Asian Journal of Beauty and Cosmetology. 2018. 16: 191-200.

Lee YC, Hwang KH, Han DH, Kim SD. Compositions of opuntia ficus-indica. The Journal of Food Science and Technology. 1997. 29: 847-853.

Moncada S, Palmer RMJ, Higgs EA. Nitric oxide: physiology, pathology, and pharmacology. Pharmacological Reviews. 1991. 43: 109-142.

Okoli CO, Akah PA, Nwafor SV, Anisiobi AI, Ibegbunam IN, Erojikwe O. Anti-inflammatory activity of hexane leaf extract of Aspilia africana C.D. Adams. Journal of Ethnopharmacology. 2007. 109: 219-225

Pasparakis M, Haase I, Nestle FO. Mechanisms regulating skin immunity and inflammation. Nature Reviews Immunology. 2014. 14: 289-301.

Noda H, Amano H, Arashima K, Hashimoto S, Nisizawa K. Studies on the antitumour activity of marine algae. Bulletin of the Japanese Society of Scientific Fisheries. 1989. 55: 1259-1264.

Song YS, Balcos MC, Yun HY, Baek KJ, Kwon NS, Kim MK, Kim DS. ERK activation by fucoidan leads to inhibition of melanogenesis in Mel-Ab cells. The Korean Journal of Physi- ology and Pharmacology. 2015. 19: 29-34.

Stierle AA, Stierle DB, Kelly K. Berkelic acid, a novel spiroketal with selective anticancer activity from an acid mine waste fungal extremophile. The Journal of Organic Chemistry. 2006. 71: 5357-5360.

Surh YJ, Chun KS, Cha HH, Han SS, Keum YS, Park KK, Lee SS Molecular mechanisms underlying chemopreventive activities of anti-inflammatory phytochemicals: down-regulation of COX-2 and iNOS through suppression of NFkB activation. Mutation Research. 2001. 480: 243-268.

Rousselle P, Braye F, Dayan G. Re-epithelialization of adult skin wounds: cellular mechanisms and therapeutic strategies. Advanced Drug Delivery Reviews, 2018.

Torres FAE, Passalacqua TG, Velásquez AMA, Souza RA, Colepicolo P, Graminha, MAS. New drugs with antiprotozoal activity from marine algae: a review. Brazilian Journal of Pharmacy. 2014. 24: 265-276.

Wiegand C, Abel M, Hipler UC, Elsner P, Effect of non-adhering dressings on promotion of fibroblast proliferation and wound healing in vitro. Scientific Reports. 2019. 9: 4320-4330.

Zang Q, Maass DL, White J, Horton JW. Cardiac mitochondrial damage and loss of ROS defense after burn injury: the beneficial effect of antioxidnat therapy. Journal of Applied Physiology. 2007. 102: 103-112.

https://doi.org/10.15616/BSL.2019.25.4.313

Cite this article as: Kim J, Lee CM, Kim SG. Phytochemical Analysis and Wound Healing Potential of Ethanol Extract of Sea Mustard and Sea Mustard Sporophyll. Biomedical Science Letters. 2019. 25: 313320. 